\title{
The Influence of Land Use To River Water Quality Level by Using The Water Quality Index Of National Sanitation Foundation (WQI-NSF) Method (Case Study: Klampok River, Semarang District)
}

\author{
Winardi D Nugraha*, Mohammad Rafif D Cahyo, and Nurandani Hardyanti \\ Environmental Engineering Department, Faculty of Engineering, Diponegoro University, Semarang, \\ 50275, Indonesia
}

\begin{abstract}
Klampok River is a river located in Semarang Regency, Central Java, which is in the Klampok Sub-watershed part of the Jragung Watershed. This 16-km-long river crosses four sub-districts in Semarang Regency, namely Bandungan, Bawen, Bergas, and Pringapus. Most of the land use along the Klampok watershed is for agricultural, residential, plantation, and industrial activities. This study aims to find out the water quality in Klampok River using Water Quality Index National Sanitation Foundation method and analyze the influence of land use and land cover (LULC) towards water quality with descriptive analysis. Land use patterns were analyzed using ArcGIS 10.3.1 software. Overall, the index value shows that the Klampok River is in good status and based on Government Regulation no. 82 of 2001, only the Fecal coliform parameter exceeded the quality standard. The highest index value (77.41) is in segment 2 with dominant land use in the form of agriculture and settlements and the lowest (73.88) in segment 4 with land use in the form of plantations, residential, and industrial activities.
\end{abstract}

\section{Introduction}

Based on data from the Central Statistics Agency (BPS) of Semarang Regency, the population of Semarang Regency in 2018 is 1,040,629 people [1]. This shows an increase of 13,140 people or $1.28 \%$ compared to 2017 . The increase in population growth rate causes various environmental degradations, as an impact in the effort to meet life needs. Changes in land cover are a form of environmental degradation which is interpreted as a form of human intervention on land to meet the life needs, both material and spiritual [2]. This land cover change occurred in several areas, including in the watershed area. A watershed is an area that functions as a catchment area that has a combination of several factors, namely vegetation, topography, soil, and humans [3]. Changes in land cover can cause some of these factors to change. As a result, the function of the watershed is

* Corresponding author: rafifdwicahyo@gmail.com 
disrupted and there can be a decline in the quality of the environment, which consequently can impact the quality of river water.

Klampok River flows in Semarang Regency which is located at coordinates between $110^{\circ} 20^{\prime} 45.5$ "to $110^{\circ} 27^{\prime} 57.1^{\prime \prime}$ East Longitude and $7^{\circ} 8^{\prime} 12.5$ "to $7^{\circ} 11^{\prime} 27.4^{\prime \prime}$ South Latitude which is a sub-watershed or one of the upstream of the Jragung watershed which empties into Demak Regency. Klampok River flows through 4 Districts namely Bandungan, Bawen, Bergas, and Pringapus. The high activity of river water utilization in the Jragung River Basin area can also cause pollution that affects river water quality. Klampok River is used by residents for various purposes such as the raw material for drinking water, bathing, washing, irrigation, agriculture, animal husbandry, and industrial activities. Hence, several parameters of water quality will increase which can indicate whether river water has been polluted mildly, moderately, or heavily. Therefore, it is necessary to analyze the effect of land use on pollution in the Klampok River.

Based on the Decree of the Minister of Environment No. 115 of 2003 concerning the Guidelines for Determination of Water Quality Status, water quality is a condition of the water that is measured and or tested based on certain parameters and certain methods, based on applicable laws and regulations. Moreover, the status of water quality is the level of water quality conditions that indicate whether a water source is in polluted conditions or good conditions at a certain time by comparing with the specified water quality standards. One method that can be used to determine the status of river water quality is the National Sanitation Foundation's Water Quality Index method. Water Quality Index is an important technique as a boundary separating surface water quality and suitability as a raw material or drinking water. The Water Quality Index is defined as a ranking technique that provides a composite effect of individual parameters of water quality on overall water quality [4]

The Water Quality Index - National Sanitation Foundation method was chosen because in general, it can show the quality of the Klampok River in 9 parameters, namely Temperature, Turbidity, Total Solid, pH, phosphate, DO, BOD, Nitrate, and Fecal Coliform. This is done by simplifying information, so that information on the quality of water can be expressed simply in a single value. WQI-NSF has been developed since 1970 by Brown, Mc Clelland, Deininger, and Tozer, in reference to the Horton Index. WQI-NSF has five water qualities: Very Good, Good, Medium/Normal, Poor, and Very Poor [5]. Furthermore, in WQI-NSF each parameter has their own weight. This is based on the magnitude of the effect of parameters on water quality.

\section{Methodology}

\subsection{Sampling Location}

This research was conducted along the Klampok Watershed with water sampling points at locations that were considered necessary to take water samples. This study was conducted in the Jragung watershed, precisely in the Klampok Sub-watershed, Semarang Regency, Central Java by taking primary data by sampling, and secondary data from Semarang Regency Environmental Services.

\subsection{Determination of the Klampok River Segment}

The determination of segmentation in this study is guided by the Minister of Environment Regulation No. 1 of 2007 based on the land use of the Klampok Sub-watershed. Classification based on land use is used to represent the potential sources of pollutants in the Klampok River. Segmentation aims to analyze the differences in the dominant pollutant 
sources between segments that can affect water quality and identify the pollutant sources. Physical data in the form of watershed boundaries, regional topography, and spatial use (land use) are used in determining river segmentation.

In addition to being based on land use, the researchers used hydrological modeling using ArcGIS 10.3.1 software through the Hydrological Toolsheet. The function of the Hydrological Toolsheet is to help model the movement of water on the surface through the Elevation Data Model (DEM).

Through the Hydrological Toolsheet, the catchment area boundaries that affect certain segments can be found. This area is defined as the total area that flows into the estuary or Pour Point. Pour Point is a point where water flows out or can use the lowest point in a subwatershed or watershed. Determination of Pour Point in river flow can help in determining the catchment area boundary in a flow.

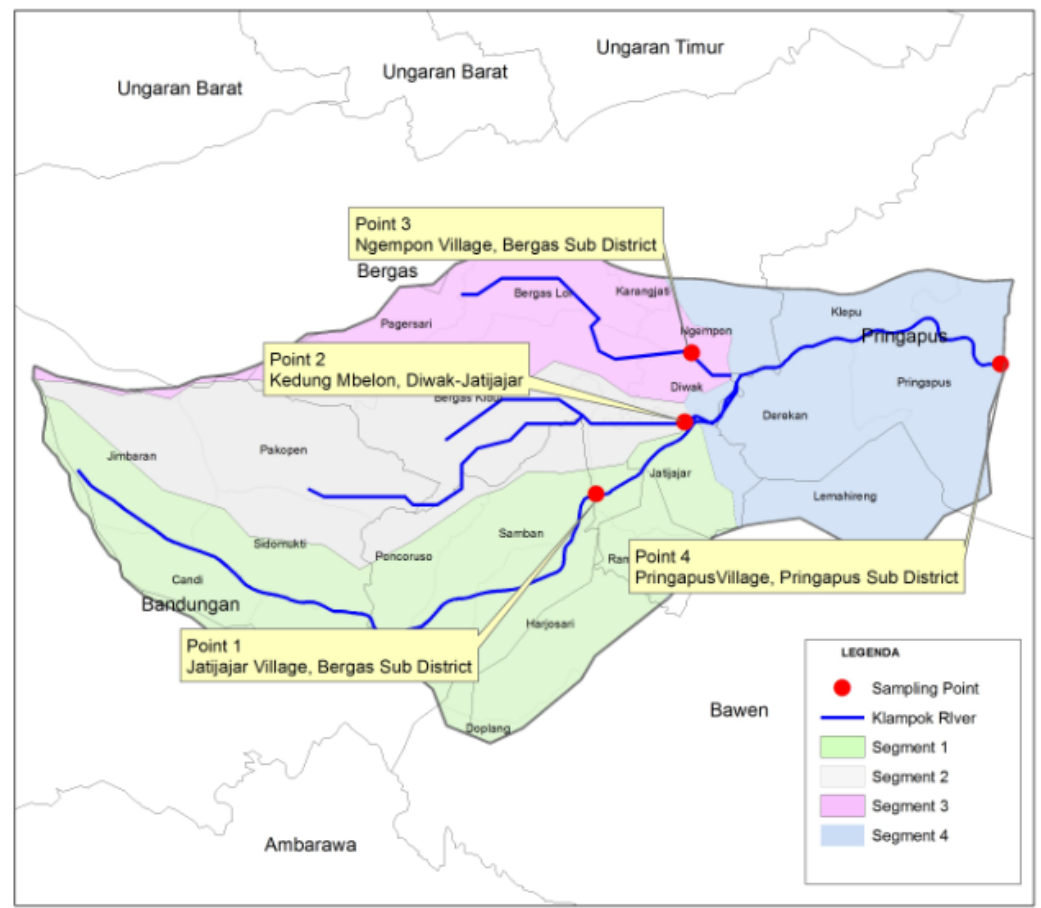

Fig. 1. Segmentation of Klampok River

Figure 1 is a segmentation map of the Klampok River. The catchment area of Segment 1 is marked in green, Segment 2 in grey, Segment 3 in purple, and Segment 4 in blue

\subsection{Determination of the Sampling Location}

Water sampling is carried out at 4 sampling points that have been determined based on the condition of the distribution of sub-watersheds, land use, topography, river physical condition, and administrative boundaries. Water sampling at the sampling location for each segment was carried out on March 4, 2020 at 08.00 - 12.45 WIB. 
Table 1. Location of the Klampok River Sampling Points

\begin{tabular}{|c|c|c|}
\hline No & Sampling Point & Coordinates \\
\hline 1. & $\begin{array}{c}\text { Sampling Point } 1 \\
\text { Located in Jatijajar Village, Bergas } \\
\text { Sub-district }\end{array}$ & $7^{\circ} 12^{\prime} 26^{\prime \prime} \mathrm{S}$ and $110^{\circ} 25^{\prime} 26^{\prime \prime} \mathrm{E}$ \\
\hline 2. & $\begin{array}{l}\text { Sampling Point } 2 \\
\text { Located in Kedung Mbelon, the } \\
\text { border between Jatijajar-Derekan, } \\
\text { Bergas Sub-district }\end{array}$ & $\begin{array}{l}7^{\circ} 11^{\prime} 59.41^{\prime \prime} \mathrm{S} \text { and } 110^{\circ} 25^{\prime} 58.82^{\prime \prime} \\
\text { E }\end{array}$ \\
\hline 3. & $\begin{array}{l}\text { Sampling Point } 3 \\
\text { Located in Ngempon Village, } \\
\text { Bergas Sub-district }\end{array}$ & $\begin{array}{c}7^{\circ} 11^{\prime} 33.72^{\prime \prime} \mathrm{S} \text { and } 110^{\circ} 26^{\prime} 1.50^{\prime \prime} \\
\mathrm{E}\end{array}$ \\
\hline 4. & $\begin{array}{l}\text { Sampling Point } 4 \\
\text { Located in Pringapus Village, } \\
\text { Pringapus Sub-district }\end{array}$ & $\begin{array}{c}7^{\circ} 11 ' 37.99 " S \text { and } 110^{\circ} 27^{\prime} 56.00^{\prime \prime} \\
\text { E }\end{array}$ \\
\hline
\end{tabular}

\subsection{Data Analysis}

Determination of the water quality status of the Klampok River using the Water Quality Index - National Sanitation Index method with 9 water quality parameters including Turbidity, Total Solid, Temperature, pH, DO, BOD, Nitrate, Total Phosphate, and Fecal Coliform.

The calculation of water quality was carried out by first determining the value of the sub-index $(\mathrm{Li})$ of each parameter based on the measured parameters of water samples in the field (xi) using a functional sub-index curve (NSF-WQI). Sub-index value (Li) of each parameter that has been obtained is then multiplied by the weight of each parameter (wi). The NSF-WQI method of Water Quality Index and description of water quality can be formulated into:

where:

$$
N S F-W Q I=\Sigma W i x L i
$$

$\mathrm{Li}=$ Parameter Sub-index

$\mathrm{Wi}=$ Parameter Weight

\section{Results and Discussions}

\subsection{Water Quality of Klampok River}

Water quality conditions need to be known to identify the level of pollution in water bodies and to determine whether water bodies are polluted or not. Water quality is the nature of water and the content of living things, energy substances, or other components in water [6]. The main parameters used for river water quality testing in this study include three parameters, which are physics, chemistry, and microbiology. Physical parameters consist of Temperature, Turbidity, and Total Solid. Chemical parameters consist of DO, BOD, Nitrate, Total Phosphate, and $\mathrm{pH}$. As for the last one, microbiological parameter measures the amount of Fecal coliform. 


\subsubsection{Temperature}

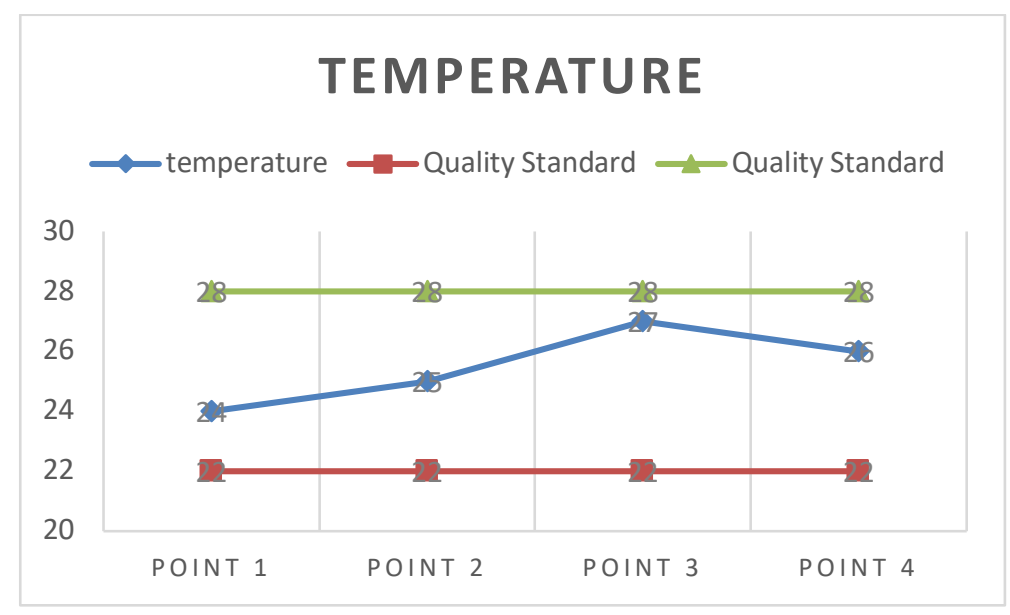

Fig. 2. Temperature Value Graph of Klampok River Temperature

Figure 2 shows that the water temperature in the Klampok River meets the Water Quality Standards with variations between $24^{\circ} \mathrm{C}$ to $27^{\circ} \mathrm{C}$. In natural waters where water bodies do not receive waste from industrial activities that can affect water temperature, temperature parameters are influenced by the intensity of sunlight entering the body of water.

\subsubsection{Turbidity}

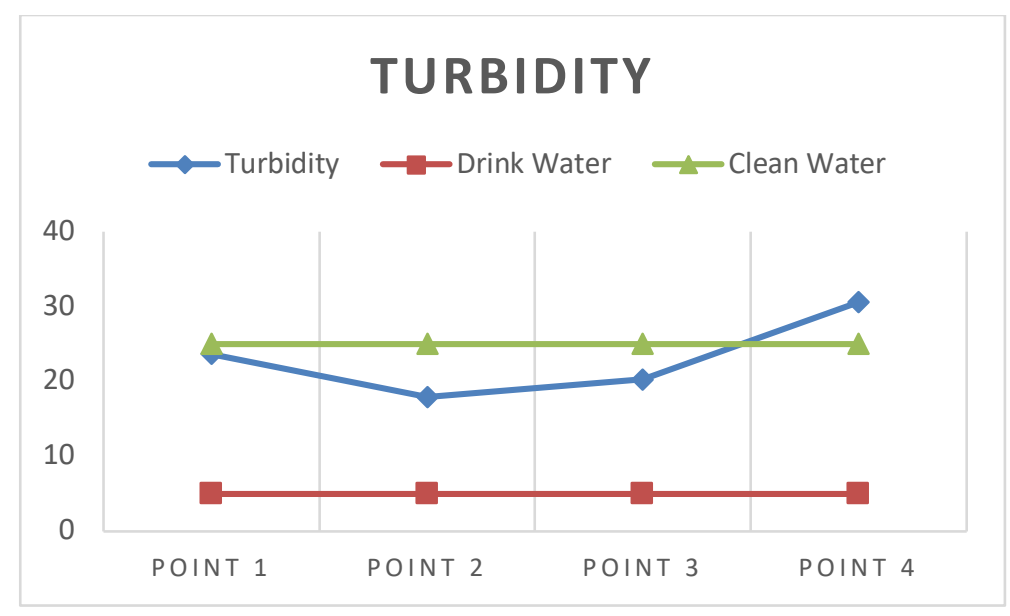

Fig. 3. Turbidity Value Graph of Klampok River

Based on the turbidity parameter analysis using the turbidimeter, it was shown that the turbidity value of the Klampok River at point 1, point 2, and point 3 still meets the allowable limit for clean water. Meanwhile, point 4 does not meet the permitted threshold for the use of drinking water or clean water. The increase of turbidity in the middle of the river occurs due to erosion around the location of the river which causes the soil to enter the water body. 


\subsubsection{Total Solid}

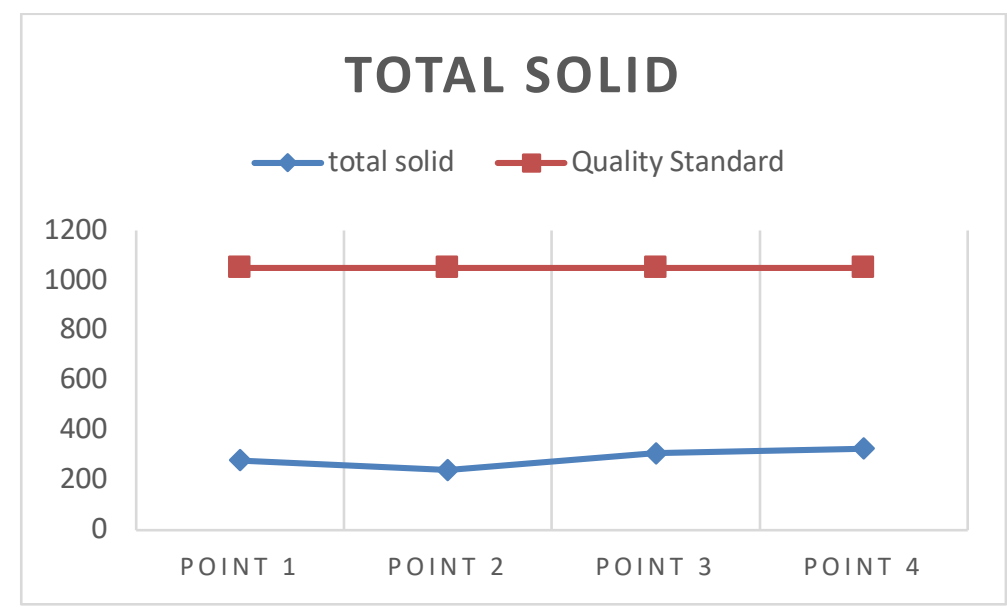

Fig. 4. Total Solid Value Graph of Klampok River

Based on the measurement results, the value of Total Solid still meets Class I and II Water Quality Standards. The highest value is at point 4, amounting to $326 \mathrm{mg} / 1$. Total Solid value is related to turbidity and strongly influenced by sediment that is not soluble in water. A past study had stated that turbidity is positively correlated with suspended solids [6]. The higher the turbidity value, the higher the value of the suspended solids. However, a high turbidity value is not always followed by a high dissolved solids value.

\subsection{4 $\mathrm{pH}$}

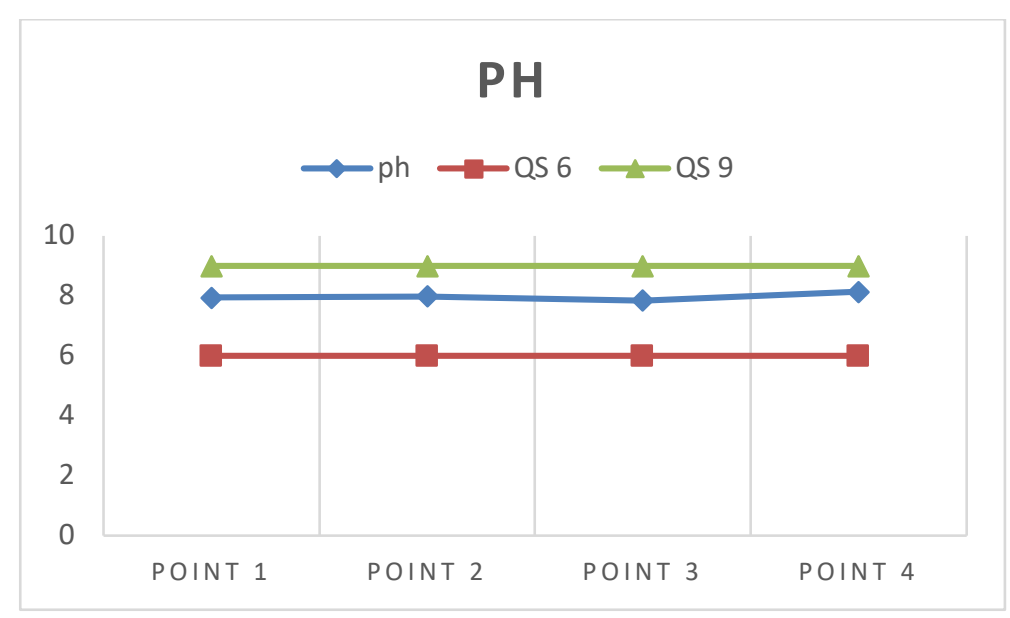

Fig. 5. pH Value Graph of Klampok River

Based on the Government Regulation No. 82/2001, the $\mathrm{pH}$ parameter for class I-III rivers is 6-9. From the results of the measurement of $\mathrm{pH}$ parameters in the Klampok River, all points meet the established quality standards with values ranging from $7.8-8.1$. 


\subsubsection{Total Phosphate}

\section{TOTAL PHOSPHATE}

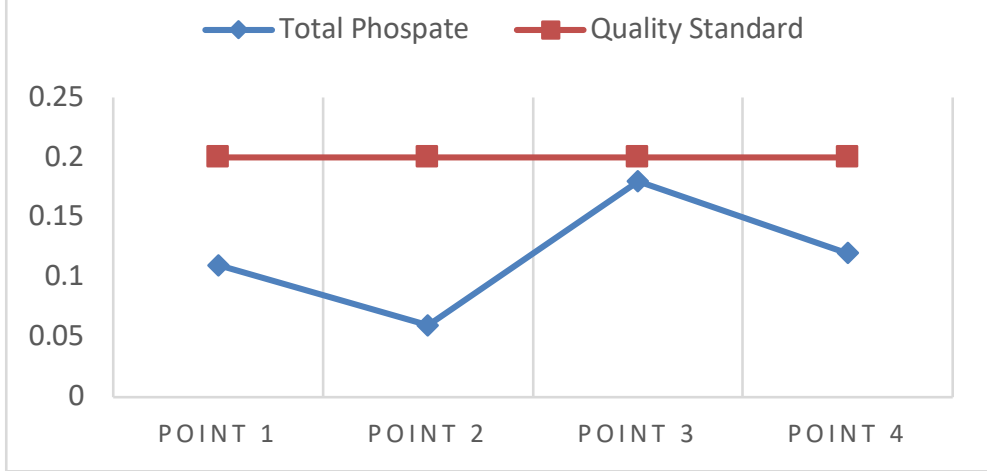

Fig. 6. Total Phosphate Value Graph of Klampok River

Based on the measurement of phosphate parameters, all sampling points indicate that the Klampok River meets quality standards based on Government Regulation No. 82 of 2001. From Figure 4.14, it can be seen that the total phosphate value has increased at point 2 to point 3 which was 0.06 to 0.18 . This can be caused by settlement and agriculture activities in the form of irrigated rice fields at that location. The increase in phosphate concentration in the Klampok River can be caused by runoff containing fertilizer that comes from agricultural activities, considering the land use at point 3 is dominated by irrigated rice fields.

\subsubsection{DO}

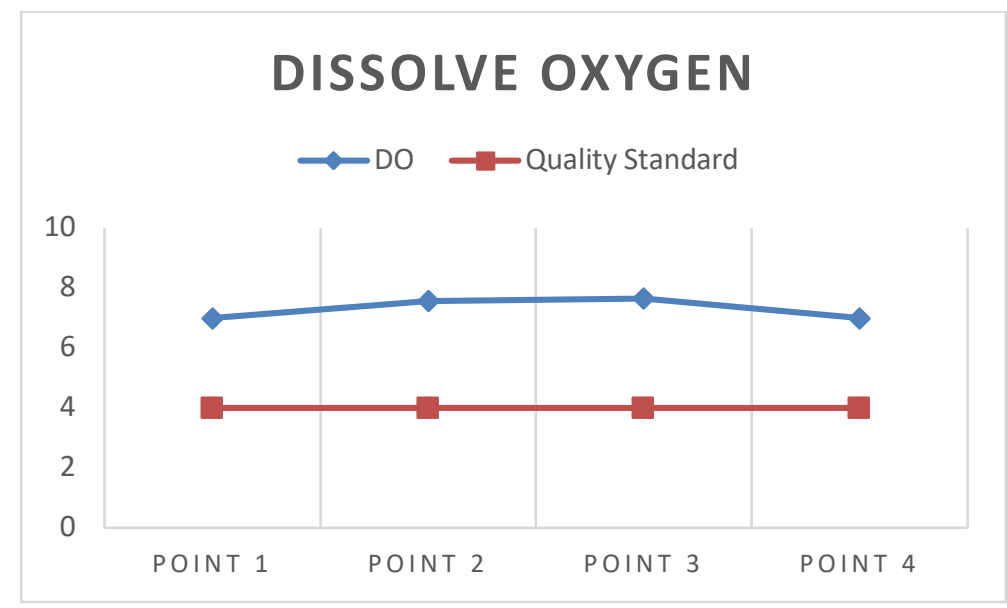

Fig. 7. DO Value Graph of Klampok River

Based on the measurement results of DO parameters, all sampling points indicate that Klampok River meets quality standards based on Government Regulation No. 82 of 2001. The Dissolve Oxygen Value of the Klampok River ranges from $7 \mathrm{mg} / 1-7.65 \mathrm{mg} / 1$. The graph of changes in Dissolve Oxygen values in the Klampok River also shows values that 
tend to be stable with no significant increase or decrease. The highest DO level occurs at point 3 , while the lowest DO level is at points 1 and 4 . Point 3 has rocky river morphology.

\subsubsection{BOD}

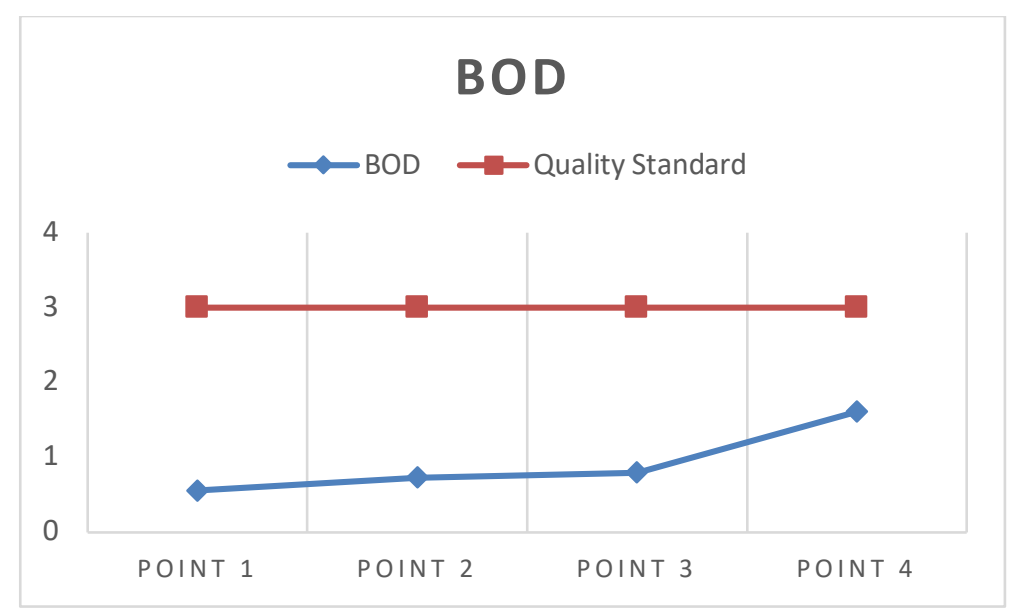

Fig. 8. BOD Value Graph of Klampok River

Based on the measurement results in Figure 7, it can be seen that the BOD values at all sampling points meet grade I water quality standards. BOD values tend to increase with values ranging from $0.56-1.61 \mathrm{mg} / 1$. The highest BOD value is at point 4 , due to the high organic matter from agricultural activities and settlements. The increase in BOD at point 4 is proportional to the drop in $\mathrm{DO}$ at point 4 . This is due to the reduction in oxygen used in the aerobic oxidation process and the use of oxygen by aquatic organisms to compensate for DO requirements.

\subsubsection{Nitrate}

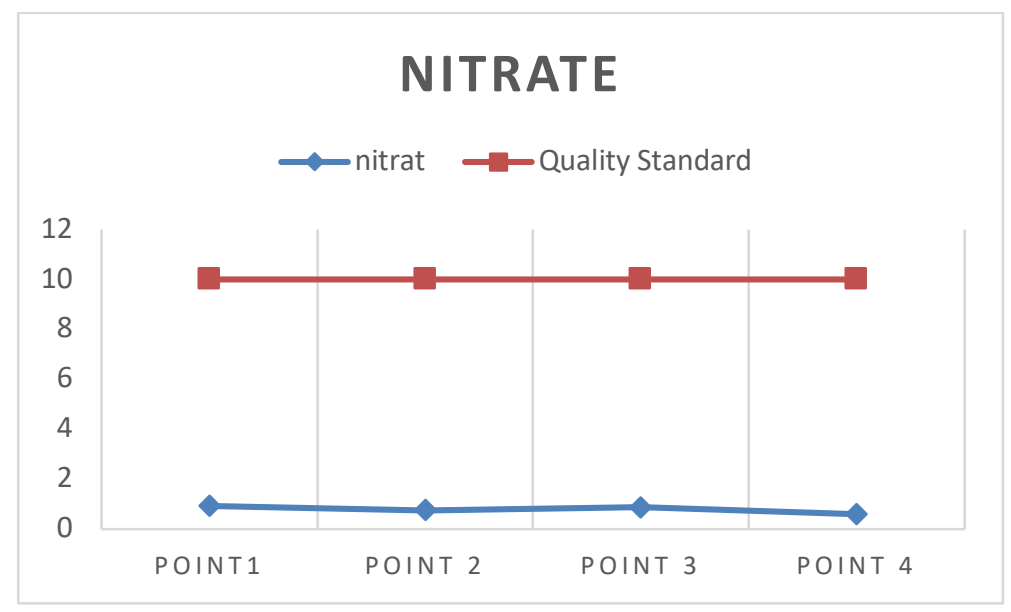

Fig. 9. Nitrate Value Graph of Klampok River 
Based on the results, the value of nitrate concentrations meet the quality standards of class I and II. The highest nitrate concentration is at point 1 at $0.93 \mathrm{mg} / 1$ while the lowest nitrate concentration is at point 4 at $0.61 \mathrm{mg} / \mathrm{l}$. The high nitrate at point 1 is caused by land use in segment 1 , which is dominated by agricultural land in the form of irrigated rice fields and rain-fed rice fields that use fertilizers with nitrate content.

\subsubsection{Fecal coliform}

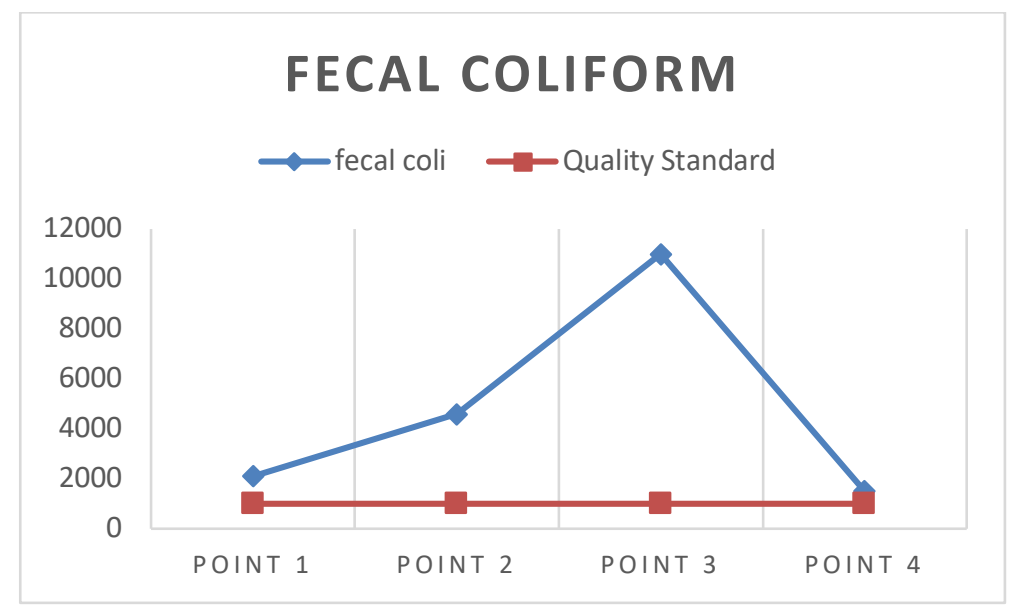

Fig. 10. Fecal Coliform Value Graph of Klampok River

From the results of measurements in Figure 9, it is shown that the measurement of Fecal coliform parameters exceeds grade II quality standards at all sampling points. This indicates that the Klampok River has experienced fecal waste pollution from both animals and humans. Fecal coliform values range from 1,500 jml / 100ml - 11,000 jml / 100ml. The highest Fecal coliform value was found at point 3 of $11,000 \mathrm{jml} / 100 \mathrm{ml}$, while the lowest value was found at point 4 of $1,500 \mathrm{jml} / 100 \mathrm{ml}$. High values in Fecal coliform bacteria indicate that the quality of sanitation around the river is still poor.

Table 2. Water Quality Value in All Sampling Points of Klampok River

\begin{tabular}{|c|c|c|c|c|c|c|}
\hline \multirow{2}{*}{ No } & \multirow{2}{*}{ Parameter } & \multirow{2}{*}{ Unit } & \multicolumn{4}{|c|}{ Sampling Point } \\
\hline & & & 1 & 2 & 3 & 4 \\
\hline 1 & Turbidity & NTU & 23,7 & 17,94 & 20,94 & 30,6 \\
\hline 2 & Total solids & $\mathrm{mg} / 1$ & 279 & 241 & 307 & 326 \\
\hline 3 & Temperature & ${ }^{\circ} \mathrm{C}$ & 24 & 25 & 27 & 26 \\
\hline 4 & $\mathrm{pH}$ & - & 7,94 & 7,99 & 7,84 & 8,14 \\
\hline 5 & $\mathrm{DO}$ & $\mathrm{mg} / 1$ & 7 & 7,57 & 7,65 & 7 \\
\hline 6 & BOD & $\mathrm{mg} / 1$ & 0,56 & 0,73 & 0,8 & 1,61 \\
\hline 7 & Nitrate & $\mathrm{mg} / \mathrm{l}$ & 0,93 & 0,76 & 0,88 & 0,6 \\
\hline 8 & $\begin{array}{l}\text { Total } \\
\text { Phosphate }\end{array}$ & $\mathrm{mg} / 1$ & 0,11 & 0,06 & 0,18 & 0,12 \\
\hline 9 & $\begin{array}{l}\text { Fecal } \\
\text { Coliform }\end{array}$ & Total $/ 100 \mathrm{ml}$ & 2100 & 4600 & 11000 & 1500 \\
\hline
\end{tabular}




\subsection{Klampok River Water Quality Based on the National Sanitation Foundation (WQI - NSF) Method}

The WQI - NSF method was developed since 1970 by Brown, McClelland, Deininger and Tozer with reference to the Horton Index. The approach to water quality assessment using the WQI - NSF method represents three parameters namely physical, chemical, and biological parameters. In the WQI-NSF method, these parameters do not stand alone but are transformed into a single value that describes water quality.

The following is a graph of changes in the value of the water quality index in each segment of the Klampok River that describes the increase and decrease in water quality based on the National Sanitation Foundation's Water Quality Index (WQI-NSF) method. Overall, the 4 Klampok River segments are still in good condition.

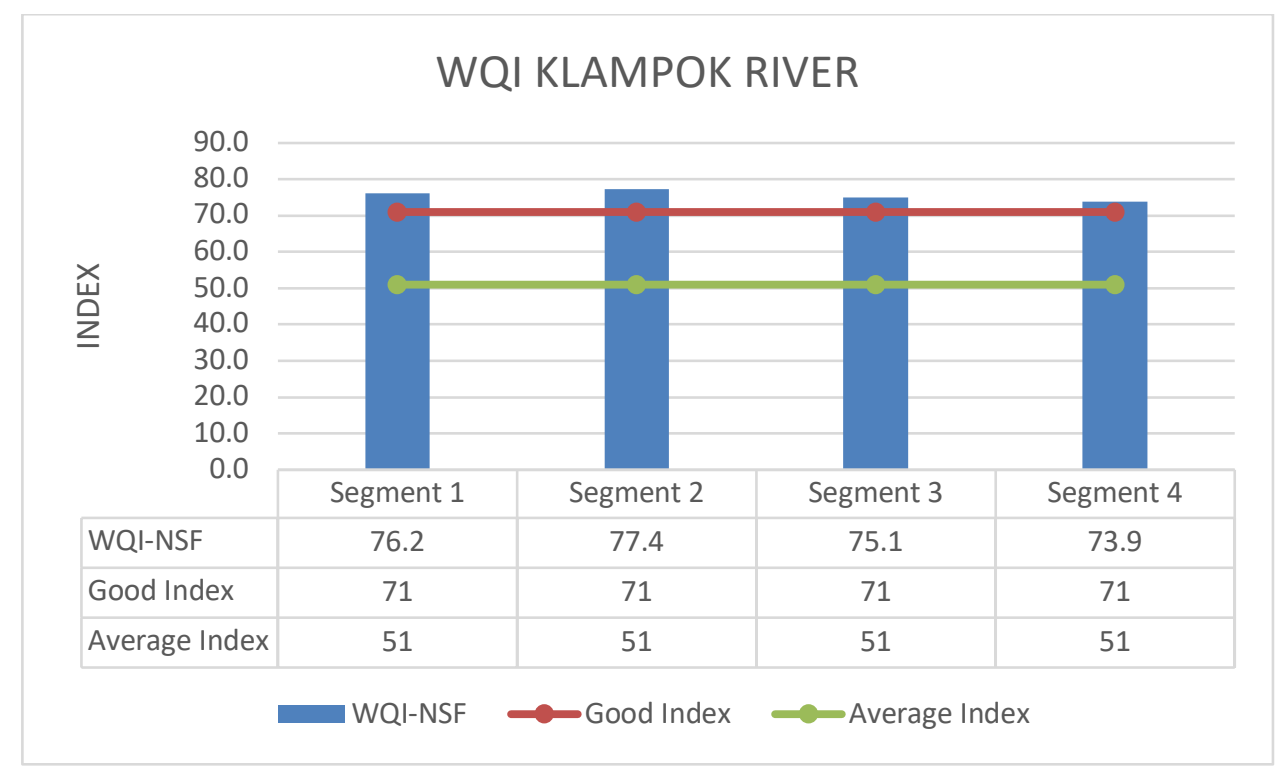

Fig. 11. WQI Value of Klampok River

Furthermore, water quality analysis for each segment using the WQI-NSF method will be explained below.

\subsubsection{Segment 1}

Segment 1 has an area of 1,282 hectares which includes 3 districts, namely Bandungan District, Bergas District, and Bawen District. The sampling point in segment 1 is located in Jatijajar Village, Bergas District. Land use in Segment 1 is dominated by rain-fed rice fields with an area of $463.13 \mathrm{Ha}$ or $36.12 \%$, then plantation with an area of $321.56 \mathrm{Ha}$ or $25.08 \%$. 


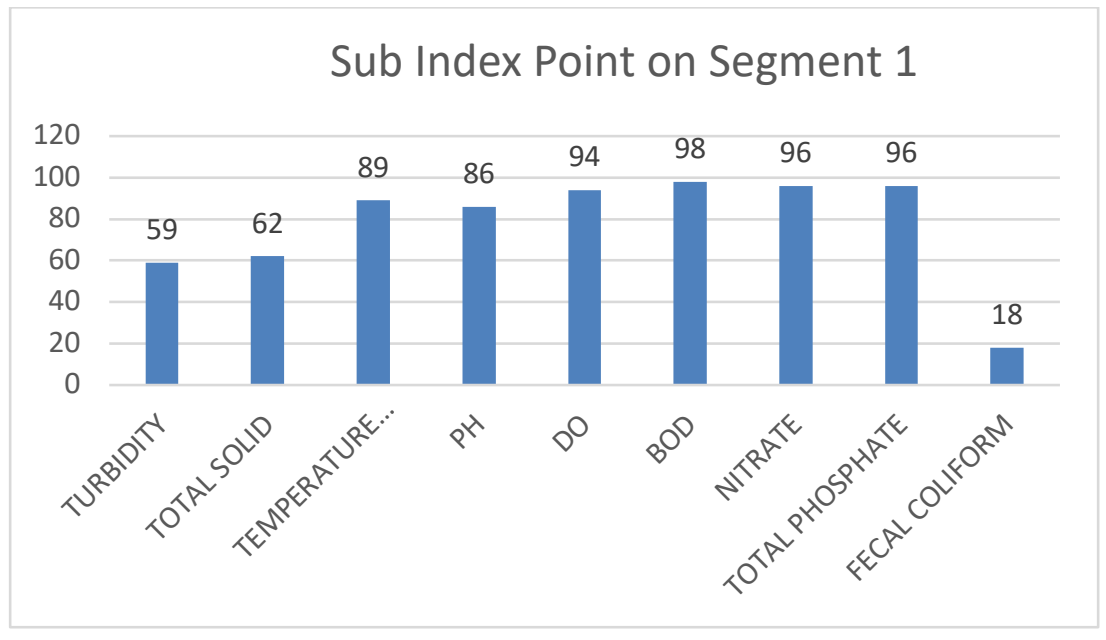

Fig. 12. Sub-index Value Diagram of Segment 1

Based on the calculation results, the water quality index in segment 1 has a value of 76.26. The index value describes that the water quality of Klampok River in Segment 1 is good. The sub-index value of Segment 1 in Fig.12 shows the sub-index value of 9 water quality constituent parameters based on the WQI-NSF method. It can be inferred from the graph that the values of Fecal coliform, total solids, and turbidity are the lowest compared to other parameters. In the assessment contained in the calculation of the water quality index, the low sub-index value reflects the high pollution in the water body. Based on the results of comparison with quality standards, only the Fecal coliform parameter that does not meet the class II river water quality standards.

The results of water quality analysis show that segment 1 had the highest nitrate levels compared to other segments. This can be influenced by land use which is dominated by agricultural land in the form of rain-fed rice fields, covering an area of 463.13 hectares or $36.12 \%$ and plantation, covering an area of 321.56 hectares or $25.08 \%$. Agricultural activities can contribute to the contamination of nitrates and phosphates in rivers. The use of agricultural land activities originating from fertilization activities and crop pest limits can produce sources of pollutants such as sediment, N, P, and pesticides [7]. Excessive use of fertilizers will usually be carried away by rainwater runoff and irrigation flow to the river.

The turbidity value in segment 1 is quite high, close to the minimum threshold for clean water. The high turbidity value is caused by sediment carried by surface runoff in the form of suspended substances or colloids which can cause high turbidity originating from agriculture. The sediment load is shown in the amount and depth of sunlight entering the water flow as measured by the turbidity that occurs [8]. High agricultural activity in the upstream can affect the increase in soil surface erosion. The high turbidity correlates with the total solid. Turbidity is positively correlated with suspended solids [6]. The higher the turbidity value, the higher the value of the suspended solids, but the high turbidity is not always followed by the high dissolved solids. The content of Fecal coliform in segment 1 is $2100 \mathrm{jml} / 100 \mathrm{ml}$. This amount exceeds the Class II water quality standard stipulated by Government Regulation No. 82 of 2001. This condition shows that segment 1 has been contaminated with Fecal coliform bacteria. E. coli bacteria dominates most of the population in fecal pollution indicators originating from humans or animals [9]. 


\subsubsection{Segment 2}

Segment 2 has an area of 896.85 Ha which includes Bandungan District, Bergas District, and a small portion of Bawen District. The land use in segment 2 is dominated by wetland agriculture. Irrigated fields are of $447.56 \mathrm{Ha}$ or $49.95 \%$, rainfed lowland of $165.41 \mathrm{Ha}$ or $18.44 \mathrm{Ha}$, and residential of $128.78 \mathrm{Ha}$ or $14.36 \%$.

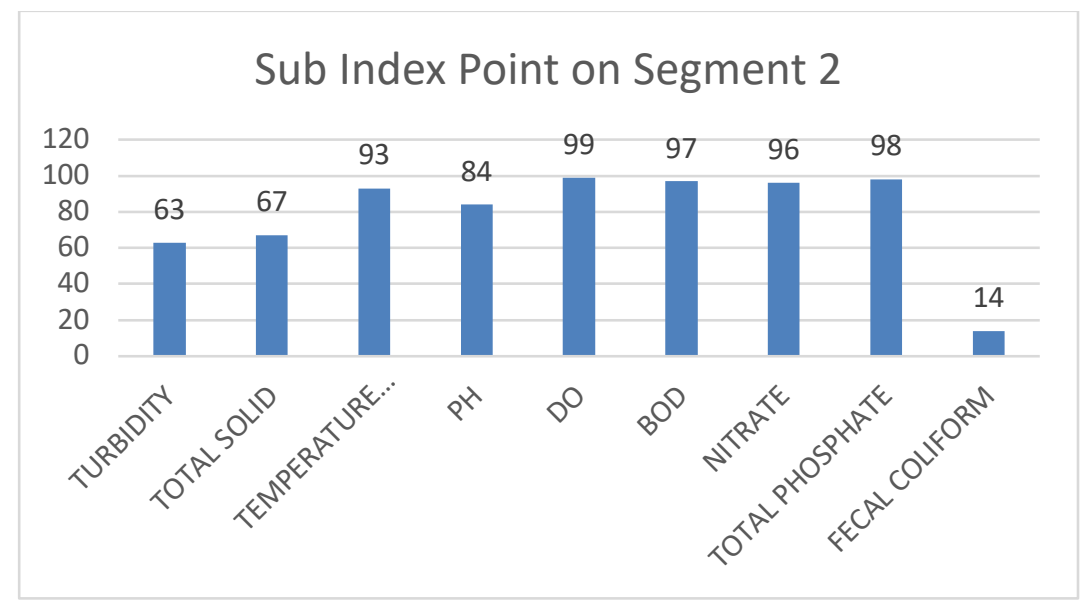

Fig. 13. Sub-index Value Diagram of Segment 2

Based on the calculation of water quality using WQI-NSF, water quality in segment 2 has the highest value compared to other segments with a value of 77.41 , thus the water quality of Klampok River in Segment 2 is classified as good. In segment 2, the water quality index value increased compared to the previous segment which indicated that the water quality had begun to improve. Fig.13 shows the sub-index value of 9 parameters making up the water quality based on the WQI-NSF method.

From the diagram, it can be seen that the Fecal coliform, total solids and turbidity have the lowest values compared to other parameters. The results of water quality analysis in segment 2 show that only the coliform fecal parameter exceeds water quality standards.

The results of water quality analysis showed a decrease in the value of nitrate compared to segment 1. The concentration of nitrate in segment 1 reached $0.93 \mathrm{mg} / 1$ while in segment 2 the concentration of nitrate dropped to $0.76 \mathrm{mg} / 1$. Nitrate is a key element in the nitrogen cycle because of the relationship between the nitrification and denitrification processes [10]. Nitrate levels in water fluctuate according to the season, with higher nitrate levels commonly occurring after heavy rains. The decrease in nitrate concentration in segment 2 was offset by high DO. Hence, when water conditions contain a lot of oxygen it will not be dangerous because a denitrification process will occur which will decrease the nitrate concentration. Low nitrate concentrations are caused due to a denitrification process, in which nitrate through nitrite will produce free nitrogen which eventually returns to ammonia [11]. The high value of DO can also be caused by the condition of segment 2 which has a lot of rock, causing turbulence that causes reaeration in water bodies [12].

Turbidity and total solid value in segment 2 are quite high, although it still meets the quality standard requirements. The high turbidity value is caused by sediment carried by surface water runoff in the form of suspended substances or colloids which can cause high turbidity. This can be due to agricultural land use that dominates this segment. Soil particles in agriculture are easily released and transported by runoff because the soil has been manipulated (in the form of agricultural land) [13]. The high turbidity affects the growth 
rate of algae (micro-aquatic plants) and other aquatic plants in streams and lakes because the increase in turbidity causes a decrease in the amount of light for photosynthesis.

The content of Fecal coliform in segment 2 is $4600 \mathrm{jml} / 100 \mathrm{ml}$. This amount exceeds the Class II water quality standard stipulated by Government Regulation No. 82 of 2001. The presence of Fecal coliform in river water bodies is identical to human or animal fecal pollution. The amount of Fecal coliform that exceeds quality standards can be harmful to human health because the Fecal coliform bacteria are positively correlated with pathogenic bacteria.

\subsubsection{Segment 3}

The segment 3 sampling point is located in Bergas Lor, Bergas District. The segment 3 area has an area of 592.02 Ha which includes Bergas District and a small portion of Bandungan District. Land use in segment 3 is dominated by irrigated rice fields, covering an area of $266.54 \mathrm{Ha}$ or $45.02 \%$, then settlements covering $173.19 \mathrm{Ha}$ or $29.25 \%$ and plantation covering 120.38 Ha or $20.33 \%$.

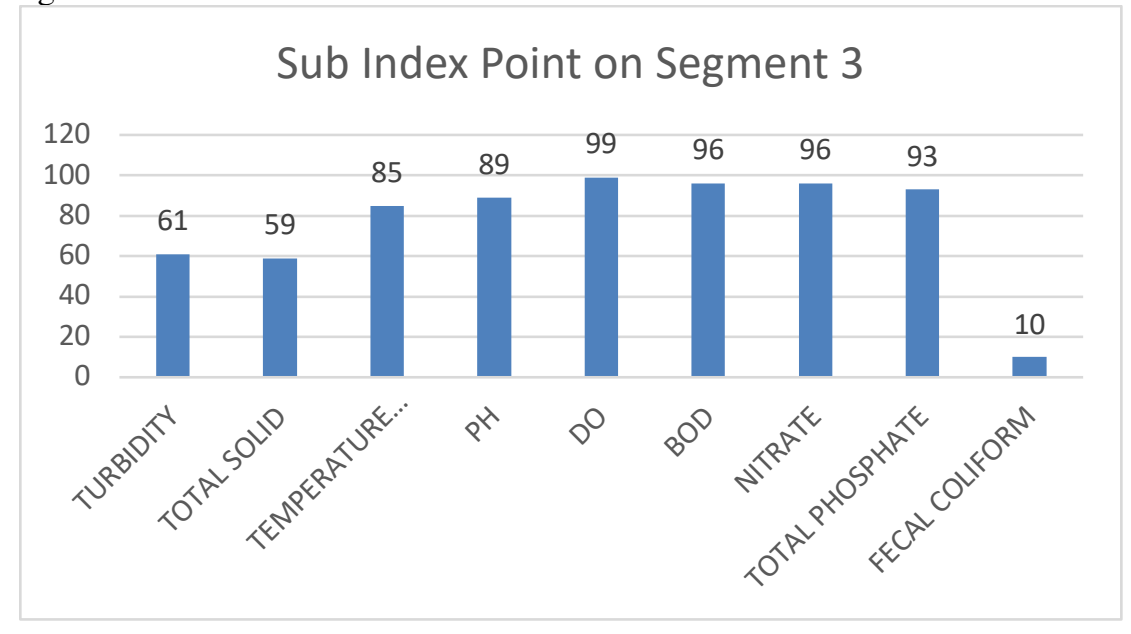

Fig. 14. Sub-index Value Diagram of Segment 3

Based on the calculation results, the water quality index in segment 3 has a value of 75.19 , thus the water quality in Klampok River Segment 3 is classified as good. The subindex value of Segment 3 in Fig. 14 shows the sub-index value of 9 water quality constituent parameters based on the WQI-NSF method. From the figure, the value of Fecal coliform, the total solids, and turbidity are the lowest compared to other parameters. In the assessment contained in the calculation of the water quality index, the low sub-index value reflects high pollution in the water body. Based on the results of comparisons with quality standards according to Government Regulation No. 82 of 2001, only the Fecal coliform parameter did not meet the class II river water quality standards.

The results of water quality analysis of total phosphate concentration in segment 3 showed the highest value compared to other segments. This can be caused by the high population and agricultural land use in segment 3. Phosphate can be found as free ions in the water system. Phosphate can be found in organic form (organically bound phosphorus) or inorganic form (including orthophosphate and polyphosphate). One of the factors that can cause high phosphate levels in water is due to the presence of domestic waste containing detergents. Detergents can increase phosphate levels because phosphate ions are one of the constituent compositions of detergents [14]. 
Phosphate is also a component used in organic and inorganic fertilizers that functions to improve soil fertility. Phosphate concentrations in water bodies that have agricultural land use are caused by intensive use of inorganic and organic fertilizers to increase soil fertility [13]. Without the control of the use of fertilizers, acidification and eutrophication will occur which in turn will make the river cannot be used as intended [15]. High nitrate and phosphate content can also cause algal growth, which can result in increased BOD concentrations because DO is used to degrade organic compounds.

The content of Fecal coliform in segment 3 is $11,000 \mathrm{jml} / 100 \mathrm{ml}$. This value is the highest compared to other segments, and also far exceeds the Class II water quality standard stipulated by Government Regulation No. 82 of 2001. The presence of bacteria, protozoa, and viruses indicates that segment 3 has been contaminated by Fecal coliform. This can be due to settlement activity in segment 3 . The main source of Escherichia coli bacteria in water bodies is one of which comes from human excretion [16]. The high Fecal coliform can also be derived from livestock activities in segment 3 . When it rains, fecal bacteria run off with dirt and enter the body of water. A past study had found that the number of Fecal coliforms was higher if there were animal husbandry near the river [17].

\subsubsection{Segment 4}

The segment 4 sampling point is located in Derekan Village, Pringapus District. Segment 4 has an area of 900.44 Ha which includes Bawen District, Begas District, and Pringapus District. Based on the analysis, the land use in segment 4 is dominated by plantation of 498.49 hectares or $55.36 \%$, irrigated rice fields of 186.39 hectares or $20.70 \%$, residential of $153,96 \mathrm{Ha}$ or $17.10 \%$, and industry of $18.88 \mathrm{Ha}$ or $2.10 \%$.

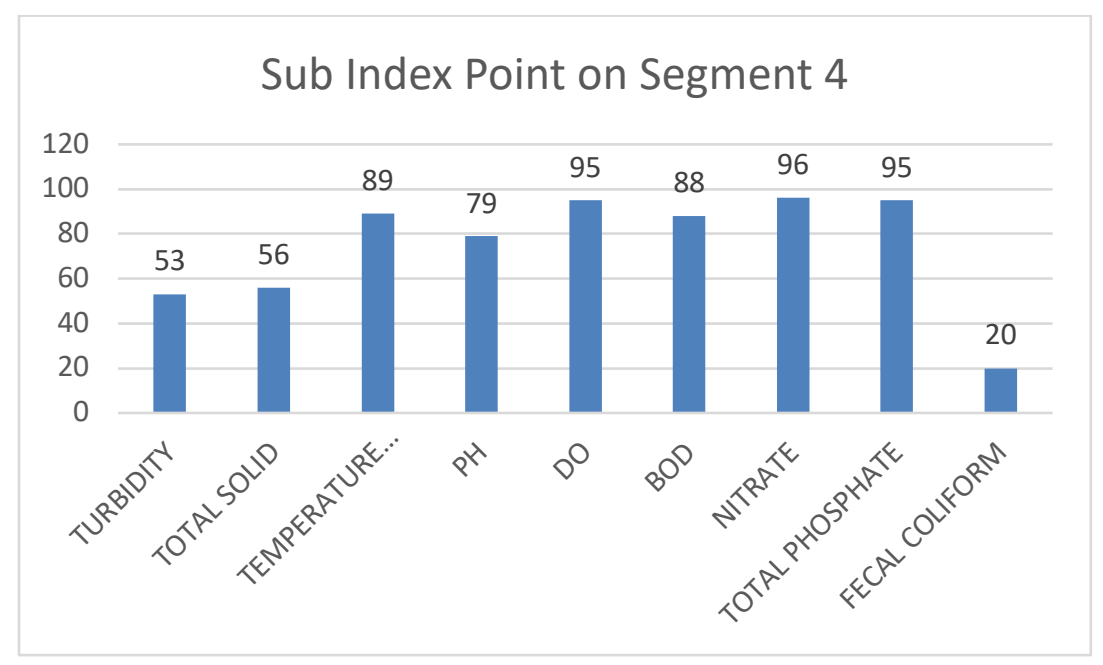

Fig. 15. Sub-index Value Diagram of Segment 4

Based on the calculation results, the water quality index in segment 4 has a value of 73.88 , thus the water quality of Klampok River in Segment 4 is classified as good. The index value in segment 4 shows a decrease compared to the previous segment. The subindex value of Segment 4 in Figure 14 shows the sub-index value of 9 water quality constituent parameters based on the WQI-NSF method. Based on these figures, the turbidity, total solids, and Fecal coliform values are the lowest compared to other parameters. Referring to water quality standards according to Government Regulation No. 
82 of 2001 and Minister of Health Regulation no. 416 of 1990, Fecal coliform parameters and turbidity does not meet quality standards.

The results of water quality analysis in segment 4 showed the highest turbidity and total solid values compared to other segments. This can be influenced by the activities of various industries, one of which is textile industry in segment 4. Ogbozige et.al. (2019) explained that there is a positive correlation between turbidity and industrial land use, in which turbidity in river water can occur due to the production of coloring activities originating from the textile industry containing various dyes. The total solids value in segment 4 also shows a high concentration compared to other segments. This can also be caused by industrial activities in segment 4 . The use of $\mathrm{NaCl}$ and sodium sulfate in industrial processes (especially the textile industry) causes the value of TDS in wastewater to increase [13]. High turbidity and total solid values can also be caused by runoff from plantations. Segment 4 is dominated by land use in the form of plantations of rubber and sengon wood. The utilization of upland land in segment 4 in the form of cornfields is also found in Pringapus and Bergas Districts.

As for the Fecal coliform parameter, the sub-index (Li) value is low and does not fulfill the quality standard. This illustrates the high concentration of Fecal coliform which reaches $1500 \mathrm{jml} / 100 \mathrm{ml}$, which means that water in segment 4 is contaminated with bacteria. Living organisms such as bacteria, protozoa, viruses, or macro-organisms such as insects can be used as indicators of pollution in water. The presence of bacteria, protozoa, viruses indicates the presence of fecal material and pathogens originating from digestion in polluted waters [18].

\section{Conclusions}

Based on the results of the research and also considering discussion in the previous chapter, the following conclusions can be drawn:

1. The water quality level of the Klampok River based on the National Sanitation Foundation's Water Quality Index (WQI-NSF) method which includes the parameters of Temperature, Turbidity, Total Solids, pH, Total Phosphate, DO, BOD5, Nitrate, and Fecal Coliform from segments 1 to 4 are classified in Good condition .

2. The level of water quality of the Klampok River is influenced by the land use conditions that are found in each segment, especially rice field agriculture and settlements. Segment areas that are affected by certain human/utilization activities dominated by agricultural land and settlements show a decrease in water quality, with the dominant pollutant parameters being turbidity, total solid, and Fecal Coliform.

\section{References}

[1] Badan Pusat Statistik Kabupaten Semarang. Kabupaten Semarang dalam Angka 2019. Kabupaten Semarang : Badan Pusat Statistik Kabupaten Semarang (2019)

[2] Arsyad S. Konservasi Tanah dan Air. Bogor: IPB Press (2006)

[3] Suripin. Pelestarian Sumberdaya Tanah dan Air. Yogyakarta: ANDI (2002)

[4] Oviantari, Made Vivi. Analisis Indeks Kualitas Air Pada Mutu Air Tlebusan Baluan, Pancoran Camplung, dan Pancoran Padukuhan di Banjar Cau, Tabanan. Seminar Nasional FMIPA Undiksha (2011)

[5] Ott, Wayne R. Environmental Indices Theory and Practice. Ann Arbor Science Inc : Michigan (1978)

[6] Effendi, Hefni. Telaah Kualitas Air. Kanisius, Yogyakarta (2003) 
[7] Dyah, Agustining. Kajian Kualitas Air Sungai Blukar Kabupaten Kendal Dalam Upaya Pengendalian Pencemaran Air Sungai. Tesis. Semarang : Program Magister Ilmu Lingkungan Program Pasca Sarjana, Universitas Diponegoro Semarang (2012)

[8] Asdak, Chay. Hidrologi dan Pengelolaan Daerah Aliran Sungai. Yogyakarta: Gadjah Mada University Press (2007)

[9] Edberg S C, Rice E W, Karlin R J, et al. Escherichia Coli: The Best Biological Drinking Water Indicator For Public Health Protection. Journal of Applied Microbiology (2000)

[10] Korostynska, O.; Mason, A.; Al-Shamma'a, A., Monitoring of Nitrates and Phosphates in Wastewater: Current Technologies and Further Challenges, International Journal on Smart Sensing and Intelligent Systems, Vol. 5 no 1, 149176 (2012)

[11] Rahman, Ega C.;Masyamsir, dan Rizal, Achmad. Kajian Variabel Kualitas Air dan Hubungannya dengan Produktivitas Primer Fitoplankton di Perairan Waduk Darma Jawa Barat, Jurnal Perikanan Kelautan, Vol. 7 no 1, 93-102 (2016)

[12] Hamid, Suhaila Abdul. Determination of Water Quality of Rivers under Various Land Use Activities Using Physico-chemical Parameters and Bacterial Populations in Northern Peninsular Malaysia. WETLAND SCIENCE, 14(6) (2016)

[13] Ogbozige, F., dan Alfa, M. Land Use-Land Cover Effects On Surface Flowing Water Quality: A Statistical Approach. Nigerian Journal Of Technological Development, 16(1). (2019)

[14] Tungka, Anggita W.; Haeruddin, dan Ain Churun, Konsentrasi Nitrat dan Ortofosfat di Muara Sungai Banjir Kanal Barat dan Kaitannya dengan Kelimpahan Fitoplanton Harmful Alga Blooms (HABs), Journal of Fisheries Science and Technology, Vol. 12 no 1, 40-46 (2016)

[15] Camargo J A, Alonso Á. Ecological And Toxicological Effects Of Inorganic Nitrogen Pollution In Aquatic Ecosystems: A Global Assessment. Environment International, 3232(6): 831-849 (2006)

[16] Domber P E, Johnson L K, Zimmerley S T, et al. Use of repetitive DNA sequences and the PCR to differentiate Escherichia coli isolates from human and animal sources. Applied and Environmental Microbiology (2000)

[17] Fernández-Alvarez R M, Carballo-Cuervo S, de la Rosa-Jorge M C, et al. The influence of agricultural run-off on bacterial populations in a river[J]. Journal of Applied Bacteriology, 7070(5): 437-442 (1991)

[18] Meays C L, Broersma K, Nordin R. Source Tracking Fecal Bacteria In Water: A Critical Review Of Current Methods. Journal of Environmental Management, 7373(1): 71-79 (2004) 